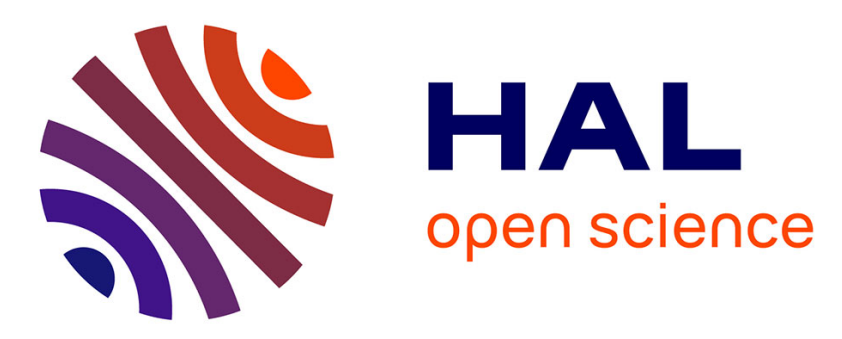

\title{
Mineralization of TiO2 nanoparticles for the determination of titanium in rat tissues
}

Jérôme Devoy, Emilie Brun, Anne Cosnefroy, Clémence Disdier, Mathieu

Melczer, Guillaume Antoine, Monique Chalansonnet, Aloïse Mabondzo

\section{- To cite this version:}

Jérôme Devoy, Emilie Brun, Anne Cosnefroy, Clémence Disdier, Mathieu Melczer, et al.. Mineralization of TiO2 nanoparticles for the determination of titanium in rat tissues. Journal of Analytical Chemistry / Zhurnal analiticheskoi khimii, 2016, 71 (4), pp.418 - 425. 10.1134/s1061934816040043 . hal-03025064

\section{HAL Id: hal-03025064 https://hal.science/hal-03025064}

Submitted on 26 Nov 2020

HAL is a multi-disciplinary open access archive for the deposit and dissemination of scientific research documents, whether they are published or not. The documents may come from teaching and research institutions in France or abroad, or from public or private research centers.
L'archive ouverte pluridisciplinaire HAL, est destinée au dépôt et à la diffusion de documents scientifiques de niveau recherche, publiés ou non, émanant des établissements d'enseignement et de recherche français ou étrangers, des laboratoires publics ou privés. 


\title{
Mineralization of $\mathrm{TiO}_{2}$ Nanoparticles for the Determination of Titanium in Rat Tissues ${ }^{1}$
}

\author{
Jérôme Devoy ${ }^{a}, *$, Emilie Brun ${ }^{b}$, Anne Cosnefroy ${ }^{c}$, Clémence Disdier $^{c}$, Mathieu Melczer $^{a}$, \\ Guillaume Antoine $^{a}$, Monique Chalansonnet ${ }^{a}$, and Aloïse Mabondzo ${ }^{c}$ \\ ${ }^{a}$ Department of Biomonitoring and Toxicology, Institut National de Recherche et de Sécurité Rue du Morvan, \\ CS 60027, F-54519 Vandoeuvre-les-Nancy, France \\ ${ }^{b}$ Laboratoire de Chimie Physique, UMR CNRS 8000, Université Paris-Sud, F-91140 Orsay, France \\ ${ }^{c} C E A$, Direction des Sciences du Vivant, iBiTec-S, Service de Pharmacologie et d'Immunoanalyse \\ F-91191, Gif-sur-Yvette, France \\ *e-mail:jerome.devoy@inrs.fr
}

Received March 15, 2015; in final form, July 27, 2015

\begin{abstract}
In order to draw appropriate conclusions about the possible adverse biological effects of titanium dioxide nanoparticles $\left(\mathbf{T i O}_{2}-\mathbf{N P s}\right)$, the so-called "dose-effect" relationship must be explored. This requires proper quantification of titanium in complex matrices such as animal organs for future toxicological studies. This study presents the method development for mineralizing $\mathrm{TiO}_{2}-\mathrm{NPs}$ for analysis of biological tissues. We compared the recovery and quantification limits of the four most commonly used mineralization methods for metal oxides. Microwave-assisted dissolution in an $\mathrm{HNO}_{3}-\mathrm{HF}$ mixture followed by $\mathrm{H}_{2} \mathrm{O}_{2}$ treatment produced the best results for a $\mathrm{TiO}_{2}-\mathrm{NPs}$ suspension, with $96 \pm 8 \%$ recovery and a limit of quantification as low as $0.9 \mu \mathrm{g} / \mathrm{L}$. This method was then used for the determination of titanium levels in tissue samples taken from rats. However, our tests revealed that even this method is not sensitive enough for quantifying titanium levels in single olfactory bulbs or hippocampus in control animals.
\end{abstract}

Keywords: titanium, nanoparticles, mineralization, toxicology, rat, ICP-MS

DOI: $10.1134 / \mathrm{S} 1061934816040043$

Titanium dioxide nanoparticles are widely produced today, with an estimated upper bound of 38000 tons per year manufactured in the United States alone [1]. They are found in many commercial products, including paint, cosmetics, pharmaceutical products, plastics, paper, ceramics, and food as an anticaking or whitening agent $[1,2]$. Such massive production raises the question of their human and environmental toxicity.

While $\mathrm{TiO}_{2}$ particles were used in the past as a negative control in vitro and in vivo toxicological studies [3], this practice was challenged after one study reported the development of lung tumors in rats after two years of exposure to high concentrations of fine $\mathrm{TiO}_{2}$ [4]. The International Agency for Research on Cancer (IARC) has therefore classified $\mathrm{TiO}_{2}$ as a Group 2B carcinogen (possibly carcinogenic to humans) [5]. Recent studies have also highlighted the ability of $\mathrm{TiO}_{2}-\mathrm{NPs}$ to cross biological barriers and reach several organs $[6,7]$. However, some absorption routes remain controversial [8-12].

\footnotetext{
${ }^{1}$ The article is published in the original.
}

One possible explanation for the discrepancies in the literature might be the difficulties involved in properly quantifying $\mathrm{TiO}_{2}-\mathrm{NPs}$ in tissue samples. Inductively coupled plasma-mass spectrometry (ICP-MS) is one of the most useful techniques available but the procedure is complicated. Sample preparation that results in acceptable and reproducible recovery, interference caused by different Ti isotopes, and estimation of the correct quantification limit in complex matrices such as biological tissues are among the hurdles to overcome. Only a few papers have dealt with this issue [13-15]. Other analytical tools, such as electrothermal vaporization ICP-MS, might be considered good alternatives for analyzing solid samples, but these often demand substantial financial investment. In this study, we developed and fully-validated a reliable, quantitative ICP-MS method for analyzing titanium contents in rat organ tissues. Different digestion/dissolution techniques are traditionally used to solubilize $\mathrm{TiO}_{2}-\mathrm{NPs}$ in organic matter, such as the use of strong acids (e.g., hydrofluoric, sulfuric and nitric acids) and/or hydrogen peroxide together with microwaves and/or heating systems [15-20]. In this study, we compared the four most common mineralization techniques for use with a $\mathrm{TiO}_{2}-\mathrm{NP}$ solution. The most 
appropriate digestion method was then selected on the basis of its recovery rate and quantification limit. This method was validated and then applied to determination of titanium in different rat organs. The results were compared to available published data. We consider determination of a method's recovery and quantification limit to be a pre-requisite and mandatory step that must be taken before analysing tissues from exposed animals and drawing conclusions about doseeffect relationships.

\section{EXPERIMENTAL}

Apparatus. A Varian 820-MS inductively coupled plasma mass spectrometer (ICP-MS) with an external sample introduction assembly with Peltier-cooled spray chamber, glass concentric nebulizer, peristaltic pump mounted outside the torch box and SPS3 auto sampler was used. A discrete dynode electron multiplier detector provides nine decades of dynamic range in an all-digital pulse design. The Varian 820-MS system also features a Collision Reaction Interface (CRI) providing fast, flexible, interference-free analysis using simple collision and reaction gases.

A Varian AA280Z Atomic Absorption Spectrophotometer (AAS), equipped with a Zeeman background corrector, was used for atomic absorption measurement of titanium at $364.3 \mathrm{~nm}$ with a slit-width of $0.5 \mathrm{~mm}$. A hollow cathode lamp of Ti (photron) was operated at $20 \mathrm{~mA}$. Uncoated graphite tube cuvettes were purchased from Schunk Kohlenstofftechnik (Germany).

Transmission electron microscopy (TEM) analyses were performed as follows: a 3- $\mu \mathrm{L}$ droplet of the dispersion was cast on formvar/carbon-coated copper grid for 2 min and imaged with a JEOL 1400 instrument (JEOL, Tokyo, Japan) operating at $80 \mathrm{keV}$ (Imagif platform, Gif-sur-Yvette). Images were acquired using a post-column high resolution (11 megapixels) high speed camera (SC1000 Orius, Gatan) and processed with Digital micrograph (Gatan) and ImageJ (Schneider Nat Meth 2012 9671) software. Hydrodynamic diameter was measured by dynamic light scattering using a ZetaSizer ZEN3600 (Malvern, Herenberg, Germany) equipped with a $633 \mathrm{~nm}$ laser. Rat samples were weighed thanks to AB204 Mettler Toledo balance.

Reagents and solutions. Certified water was used (Trace Metals 3, RTC, QC1448). All chemicals used in the study were of analytical grade or higher. Nitric acid was used to prepare $2.0 \% \mathrm{HNO}_{3}(\mathrm{v} / \mathrm{v})$ with ultrapure water. All single element stock solutions $(1000 \mathrm{mg} / \mathrm{L})$ were delivered by SCP Science and certified for purity and concentration. Titanium standard solutions for ICP-MS calibration were prepared (at concentration levels of 50 to $10000 \mathrm{ng} / \mathrm{L}$ ) by diluting a $10 \mathrm{~g} / \mathrm{L}$ titanium standard stock solution (140.050.220, SCP Science) with $2 \%(\mathrm{v} / \mathrm{v}) \mathrm{HNO}_{3}$. An internal stan- dard solution containing $100 \mu \mathrm{g} / \mathrm{L}$ of Ge was prepared by diluting a $1000 \mathrm{mg} / \mathrm{L}$ internal standard stock solution (140.051.211, SCP Science) with $2 \%$ (v/v) $\mathrm{HNO}_{3}$. The internal standard was added to all samples and standard solutions.

External quality assurance was performed by participation in the following international comparison programs and quality assessment schemes: German External Quality Assessment Scheme (G-EQUAS) from the Institute and Out-Patient Clinic for Occupational, Social and Environmental Medicine at Friedrich-Alexander-University, Erlangen-Nuremberg, Germany, and Quebec Multielement External Quality Assessment Scheme (QMEQAS) at the Canadian Institut National de Santé Publique du Québec.

Titanium dioxide nanoparticle preparation. The $\mathrm{TiO}_{2}-\mathrm{NPs}$ used in this study were in the form of Aeroxide ${ }^{\circledR}$ P25 $\mathrm{TiO}_{2}$ (Degussa, Sigma Aldrich), which consists of an 81:19 mixture of anatase and rutile. A stock solution was prepared by adding the desired weight of P25 to ultrapure water (MilliQ, Millipore, Germany) and sonicating for $30 \mathrm{~min}$ in a Branson 2510 bath sonicator at a frequency of $40 \mathrm{kHz}$. The morphology and size of $\mathrm{TiO}_{2}-\mathrm{NPs}$ in stock suspensions were determined by TEM. The mean particle diameter as observed by TEM was $21 \pm 7 \mathrm{~nm}(n=$ 300). From dynamic light scattering measurements, $\mathrm{TiO}_{2}-\mathrm{NPs}$ were found to agglomerate in both water and culture medium (474 $\pm 96 \mathrm{~nm}$ in distilled water and $747 \pm 142 \mathrm{~nm}$ in culture media). The specific surface area (BET) was $50 \pm 15 \mathrm{~m}^{2} / \mathrm{g}$. Various concentrations for the digestion evaluation were made using a serial dilution of the stock solution. First, $125 \mathrm{mg}$ of $\mathrm{TiO}_{2}-\mathrm{NPs}$ powder was dispersed in $50 \mathrm{~mL}$ of distilled water. The $2.5 \mathrm{~g} / \mathrm{L}$ suspension was then treated by ultrasound for $20 \mathrm{~min}$ and mechanically vibrated for $3 \mathrm{~min}$. An intermediate suspension at $2.5 \mathrm{mg} / \mathrm{L}$ was prepared in order to prepare final solutions of $2 \mu \mathrm{g} / \mathrm{L}$ for testing the stability/homogeneity of the solution, and $5 \mu \mathrm{g} / \mathrm{L}$ for testing the mineralization methods.

Animal tissue samples. All experiments in this study were performed in line with the European guidelines related to the protection of animals used for experimental and other scientific purposes [21]. Prior to the study period, 62 eight-week-old male Sprague-Dawley rats (Charles River, Domaine des Oncins, SaintGermain-sur-l'Arbresle, France), each weighing 250$275 \mathrm{~g}$, were housed under controlled environmental conditions for seven days in polycarbonate cages (43 cm long, $43 \mathrm{~cm}$ wide, $19 \mathrm{~cm}$ high, each holding six rats) with hardwood-chip bedding. The room temperature $\left(22^{\circ} \mathrm{C}\right)$, humidity $(55 \pm 5 \%)$ and light cycle (07:00-19:00 h) were controlled automatically. Filtered tap water (pore size $0.3 \mu \mathrm{m}$ ) and $\gamma$-ray-sterilized food (UAR-Alimentation, Villemoisson, Epinay-surOrge, France) were provided ad libitum.

Animals were deeply anesthetized with pentobarbital $(60 \mathrm{mg} / \mathrm{kg})$ and then killed by exsanguinations 
through the abdominal aorta. Blood samples were taken and red blood cells (RBC) were isolated from plasma for the determination of titanium. Tissue and organs (brain, liver, spleen, kidneys, lungs) were collected and weighed. The brains of 46 rats were removed rapidly and then placed on glass plates at $0^{\circ} \mathrm{C}$ to sample the olfactory bulbs, hippocampus, frontal cortex and cerebellum. Tissue samples were placed in polyethylene microcentrifuge tubes and immediately put into liquid nitrogen storage at $-180^{\circ} \mathrm{C}$ until analysis. All procedures used in this experiment were compliant with the local ethics committee.

Mineralization methods. The four most commonlyused digestion methods were tested (methods A to D, below). Method A is described by Wang [22] and Liu [23], and methods B, C and D are presented in Khosravi [24]. For each method, tissues were removed from storage and thawed. About $0.1-0.3 \mathrm{~g}$ of each tissue was weighed and digested.

Method A. Several hundred $\mathrm{mg}$ of sample was digested overnight in $2 \mathrm{~mL}$ of concentrated nitric acid. After adding $0.5 \mathrm{~mL}$ of concentrated $\mathrm{H}_{2} \mathrm{O}_{2}$, the mixed solutions were digested completely using a Microwave Assisted Reaction System (MARS) Express instrument. The microwave digestion program consisted of a temperature ramp to $150^{\circ} \mathrm{C}$ over $15 \mathrm{~min}$, followed by a ramp from 150 to $180^{\circ} \mathrm{C}$ over $15 \mathrm{~min}$ and then a 20 min hold at $180^{\circ} \mathrm{C}$. Power was at $1200 \mathrm{~W}$ during the 50 -min cycle. The MARS reactors were rinsed twice with $10 \mathrm{~mL}$ of $2 \%$ nitric acid and then transferred to a Teflon reaction vessel containing the sample solution. The solutions were heated at $120^{\circ} \mathrm{C}$ until colourless and clear in order to remove the remaining nitric acid. Finally, the remaining solutions were diluted to $3 \mathrm{~mL}$ with $2 \%$ nitric acid and then analyzed for titanium content.

Method B. A tri-acid mixture was prepared with concentrated nitric, hydrochloric and hydrofluoric acids mixed in a ratio of $3: 1: 3$, and $30 \mathrm{~mL}$ of this mixture was added to each Teflon reaction vessel containing a sample. The mixed solutions were then completely digested using MARS Express instrument. The microwave digestion program was the same as that used for method A. After cooling, the remaining solution was diluted with $10 \mathrm{~mL}$ of ultrapure water. The aqueous solution was transferred to volumetric flasks for appropriate dilution (ten-fold typically) and then analyzed for titanium content.

Method C. Samples were added to a $55 \mathrm{~mL}$ microwave digestion vessel with $8 \mathrm{~mL}$ of concentrated nitric acid and $2 \mathrm{~mL}$ of concentrated HF. The samples were digested using MARS Express instrument, following the same temperature program as that used for methods A and B. After cooling, the vessel was rinsed at least three times into a Teflon beaker using approximately $20 \mathrm{~mL}$ of a $2 \%$ nitric acid solution, and $2 \mathrm{~mL}$ of concentrated hydrogen peroxide was added to each beaker to digest any remaining organics. The beakers were then heated on a hot plate at $180^{\circ} \mathrm{C}$ until 0.1 to $0.5 \mathrm{~mL}$ of each solution remained. The beakers were then removed from the hot plate, allowed to cool and rinsed at least three times into a $25 \mathrm{~mL}$ volumetric flask using a $2 \%$ nitric acid solution before being stored for analysis. The final concentration of HF in the measured solution was low enough to allow using the routinely applied sample introduction system.

Method D. Samples were transferred to porcelain crucibles for digestion and heated gently to dryness over a hot plate. To optimize the persulfate fusion method, various amounts of ammonium persulfate were added to the crucible. Care was taken to ensure that the residue at the bottom of the crucible was completely covered with ammonium persulfate prior to fusion, and all the steps in the digestion process took place in an acid-resistant fume hood. Fusion was initiated by heating with a laboratory Bunsen burner. Upon heating of the reaction vessel, the mixture began to fume. Fusion was complete once fuming had ceased (after about $3 \mathrm{~min}$ ). The fusion product was soaked in $10 \mathrm{~mL}$ of $2 \%$ nitric acid solution in the reaction vessel for $30 \mathrm{~min}$. The solution was then relocated into a $200 \mathrm{~mL}$ flask and placed on a hotplate for further digestion by gentle boiling for $10 \mathrm{~min}$. Finally, the clear solution was transferred to a $50 \mathrm{~mL}$ volumetric flask and diluted with $2 \%$ nitric acid solution.

Determination of titanium. Prior to elemental analysis, the tissues were mineralized according to one of the methods described above. In general, ICP-MS was used to measure titanium concentrations in the samples. The typical method parameters (including CRI settings) used for the analyses are listed in Table 1. Analytical parameters for AAS are presented in Table 2. The internal standard concentration was $50 \mu \mathrm{g} / \mathrm{L} \mathrm{Ge}$ for all samples and calibration solutions. Blanks and tissue digests were measured against an external calibration with internal standard correction.

Titanium determination by conventional quadrupole ICP-MS has recently been optimized [15]. Unwanted interferences can also be minimized using collision/reaction cell technology [25]. For titanium determination with Varian 820-MS, the samples were injected directly. In order to avoid potential interferences [13], the analyses were performed in CRI mode on ${ }^{49} \mathrm{Ti}$, an isotope that has a relatively low natural abundance $(5.4 \%)$. In order to cross-check the ICP-MS results, the same samples were analyzed by AAS when possible. The data were expressed either as micrograms per liter of digestion solution or as micrograms per gram of fresh tissue. ICP-MS was sensitive enough to quantify all of our samples and there was no need to improve the analytical quantification limit of $0.08 \mu \mathrm{g} / \mathrm{L}$. In contrast, a significant effort was made to improve the method quantification limits (MQL).

Quantification limits. The limit of quantification (LOQ) can be estimated by taking 30 repeat measurements of the blank in the same series. The mean and 
Table 1. Instrumental settings for the determination of titanium in $\mathrm{HNO}_{3}$ solution by $\mathrm{ICP}-\mathrm{MS}$

\begin{tabular}{l|l|c}
\hline \multicolumn{1}{c|}{ Parameter } & \multicolumn{1}{|c}{ Instrument parameter } & Setting \\
\hline Gas flow parameters, L/min & Plasma flow & 13.5 \\
& Auxiliary fow & 1.35 \\
& Nebulizer flow & 1.00 \\
& Sheath flow & 0.19 \\
\hline Plasma power & RF power, kW & 1.40 \\
\hline Sample introduction & Sampling depth, mm & 7.0 \\
& Pump rate, rpm & 5.0 \\
\hline Ion optics, V & First extraction lens & -10 \\
& Second extraction lens & -90 \\
& Third extraction lens & -32 \\
& Corner lens & -310 \\
& Mirror lens left & 35 \\
& Mirror lens right & 19 \\
& Mirror lens bottom & 26 \\
& Fringe bias & -7.0 \\
\hline CRI Gas settings & Skimmer gas source & He \\
& Skimmer flow, mL/min & 150 \\
\hline Quadrupole scan & Scan mode & Peak hopping \\
& Dwell time, ms & 100 \\
& Points per peak & 1 \\
& Scans/replicate & 20 \\
& Replicates/sample & 3 \\
\hline
\end{tabular}

standard deviation (SD) of these 30 measurements are expressed in concentration. In this case, the LOQ is equal to the sum of the mean blank concentration plus ten standard deviations. Alternatively, the LOQ can be evaluated using the dilution of a standard solution or quality control sample at a low concentration with the dilutant. Eleven dilutions are prepared, altering the dilution by $10 \%$ each time (i.e., $100+0,90+10,80+$ $20 \ldots 0+100)$, and each preparation is measured 10 times in a single series. To determine the LOQ, the standard deviation and variation of the average $(\mathrm{m})$ from the theoretical value (fidelity profile) are calculated for each series of measurements. The concentrations and their respective SD values are then used to construct a Horwitz curve from which the LOQ can be extrapolated at $\mathrm{SD}=15 \%$. We chose the first way to estimate LOQ and we verified the consistency of this limit with the second way.

Method validation. Validation was done as described in our previous paper [26]. The linearity limit, precision (intermediate precision, repeatability and reproducibility), accuracy and sensitivity were estimated for the chosen method. This validation procedure is in good agreement with that proposed by Peters et al. [27].

\section{RESULTS AND DISCUSSION}

Stability and homogeneity of $\mathrm{TiO}_{2}-\mathrm{NPs}$ solution. To be sure that the solution was homogeneous and stable, the concentration of an initial $2 \mu \mathrm{g} / \mathrm{L} \mathrm{TiO}_{2}-\mathrm{NPs}$ aqueous solution $(250 \mathrm{~mL})$ was monitored at different times over $360 \mathrm{~min} ; t=0$ corresponds to the end of ultrasonic and vibration treatment. An aliquot of $50 \mu \mathrm{L}$ was sampled at different times $(t=0,10,15,60$, $90,120,180,240,300$ and $360 \mathrm{~min}$ ) and transferred to a $50 \mathrm{~mL}$ flask of $2 \% \mathrm{HNO}_{3}$. A ten-fold dilution was performed for each of these aliquots prior to graphite furnace (GF)-AAS analysis. At this level of titanium concentration, the GF is capable of direct analysis of solids [28], thus allowing the problem of $\mathrm{TiO}_{2}-\mathrm{NPs}$ mineralization to be avoided. Fifteen analyses of this stock solution were performed over $360 \mathrm{~min}$. The mean $\mathrm{TiO}_{2}$ concentration was $2.0 \mu \mathrm{g} / \mathrm{L}$ with a SD of $0.3 \mu \mathrm{g} / \mathrm{L}(\mathrm{RSD}=16 \%)$. A review of Cal-Prieto et al. [29] reported the RSD values for elemental analysis of animal tissue with GF-AAS ranging from 14 to $17 \%$. The stock solution was therefore considered stable enough to be analyzed in our experimental conditions.

Recovery. The digestions were first evaluated for the recovery of the $2 \mu \mathrm{g} / \mathrm{L} \mathrm{TiO}_{2} \mathrm{NPs}$ aqueous solution. Twelve aliquots of this solution were used for each 
Table 2. Instrumental settings for the determination of titanium in $\mathrm{HNO}_{3}$ solution by GF-AAS

\begin{tabular}{l|c}
\multicolumn{1}{c|}{ Parameter } & Value \\
\hline Wavelength, nm & 364.3 \\
Lamp current, mA & 20 \\
Slit width, nm & 0.5 \\
Dry temperature, ${ }^{\circ} \mathrm{C}$ & 120 \\
Dry time, ramp/hold, s & $40 / 30$ \\
Ashing temperature, ${ }^{\circ} \mathrm{C}$ & 1300 \\
Ashing time, ramp/hold, s & $20 / 10$ \\
Atomisation temperature, ${ }^{\circ} \mathrm{C}$ & 2800 \\
Atomisation time, ramp/hold, s & $1.2 / 3$ \\
Cleaning temperature, ${ }^{\circ} \mathrm{C}$ & 2800 \\
Cleaning time, ramp/hold, s & $2 / 0.4$ \\
\hline
\end{tabular}

digestion method. The results are presented in Table 3. The recovery rates of methods $\mathrm{B}, \mathrm{C}$ and $\mathrm{D}$ were over 92\% with standard deviations below $9 \%$. At this concentration level, a SD below $15 \%$ is equivalent to the $\mathrm{SD}$ values determined for quality control samples. In contrast, method A had a recovery rate of $56 \%$ and a SD of about $25 \%$. These data were also used to determine the digestion MDL.

Quantification limits. All digestion methods were applied to blank samples in order to measure the likely amounts of titanium contamination. Teflon tubes, $15 \mathrm{~mL}$ polypropylene tubes and chemicals are all potential sources of titanium contamination [15]. One of the main advantages of using real blank samples to estimate the MQL is that any titanium contamination will be entirely integrated into the MQL.

As a further safeguard and quality check for titanium contamination, the vessels were rinsed in between two consecutive quantitative analyses, fol- lowing the protocol of method $\mathrm{C}$, and the final solution was analyzed. If the titanium content was higher than $0.4 \mu \mathrm{g} / \mathrm{L}$, the vessels were rinsed again and reanalyzed. This "contamination limit" was arbitrarily chosen but was later found to have yielded the best results. The quantification limits for each method are reported in Table 3. Titanium blank concentrations ranged from 0.3 to $1.3 \mu \mathrm{g} / \mathrm{L}$ depending on the method. MQL averages and standard deviations are also reported. Of the three methods, method $\mathrm{C}$ yielded the highest sensitivity (MQL $=0.9 \mu \mathrm{g} / \mathrm{L})$ and a satisfactory recovery rate $(96 \pm 8 \%)$. This method was therefore chosen for the analyses of biological samples.

Validation of the method. Linearity was investigated using 6 standard solutions with concentrations ranging from 0.8 to $52 \mu \mathrm{g} / \mathrm{L}$ ( 6 replicates). The linearity of the calibration curves for ${ }^{49} \mathrm{Ti}$ was good over this concentration range $\left(R^{2}>0.999\right)$. The intermediate precision at any given level is defined as the degree of concordance between individual results obtained from a single sample tested in a single laboratory, but where one or more of the analyst, equipment and/or day varies. The intermediate precision was determined at two titanium concentrations: 1.24 and $6.20 \mu \mathrm{g} / \mathrm{L}$. Samples were analyzed twice per day over 15 days. The maximum standard deviation was $22 \%$. The standard deviations obtained for 1.24 and $6.20 \mu \mathrm{g} / \mathrm{L}$ solutions were 6.6 and $3.5 \%$, respectively.

The accuracy at any given level is the degree of concordance between the value certified by a recognized organization and the mean result obtained by applying the experimental procedure at least ten times. Accuracy was measured at the two titanium concentrations, 1.24 and $6.20 \mu \mathrm{g} / \mathrm{L}$. Thirty replicates of the samples were performed. The accuracies were 99.91 and 99.97\%, respectively.

Matrix effects and recovery rates were doublechecked by analyzing the titanium content of samples

Table 3. Recovery rates and quantification limits for each method (mean values \pm SD)

\begin{tabular}{c|c|c|c|c|c}
\hline Method & Recovery*, \% & $\begin{array}{c}\text { Expected titanium } \\
\text { concentration, } \\
\mu \mathrm{g} / \mathrm{L}\end{array}$ & $\begin{array}{c}\text { Mean titanium } \\
\text { concentration, } \\
\mu \mathrm{g} / \mathrm{L}\end{array}$ & $\begin{array}{c}\text { Blank mean } \\
\text { titanium } \\
\text { concentration, } \\
\mu \mathrm{g} / \mathrm{L}\end{array}$ & $\mathrm{LOQ}^{* *}, \mu \mathrm{g} / \mathrm{L}$ \\
\hline $\mathrm{A}$ & $56 \pm 25$ & 5.4 & $3.0 \pm 1.4$ & $1.2 \pm 0.2$ & 3.7 \\
B & $98 \pm 3$ & 5.0 & $4.9 \pm 0.2$ & $0.5 \pm 0.1$ & 1.2 \\
$\mathrm{C}$ & $96 \pm 8$ & 5.2 & $5.0 \pm 0.4$ & $0.3 \pm 0.1$ & 0.9 \\
$\mathrm{D}$ & $92 \pm 9$ & 4.8 & $4.5 \pm 0.4$ & $1.3 \pm 0.1$ & 2.6 \\
\hline
\end{tabular}

* For recovery, there were 12 sample repetitions, or 12 independent sample digestions; each sample was measured in triplicate.

** For LOQ, there were 30 sample repetitions; each sample was measured in triplicate; LOQ = mean + 10SD; instrumental quantification limit is equal to $0.08 \mu \mathrm{g} / \mathrm{L}$. 
Table 4. Quantification limits for rat tissue samples

\begin{tabular}{l|c|c|c|c|c}
\hline \multicolumn{1}{c|}{ Rat matrices/organs } & $\begin{array}{c}\text { Average sample } \\
\text { mass, mg }\end{array}$ & $\begin{array}{c}\text { Mean titanium } \\
\text { concentration, } \\
\mu \mathrm{g} / \mathrm{L}\end{array}$ & $\begin{array}{c}\text { Mean titanium } \\
\text { concentration, } \\
\mathrm{ng} / \mathrm{g}\end{array}$ & LOQ, ng/g & LOD, ng/g \\
\hline Brain $(n=16)$ & $1606 \pm 388$ & $4.8 \pm 1.7$ & $74.8 \pm 17.8$ & 13.7 & 4.1 \\
Liver & $4738 \pm 1259$ & $21.1 \pm 11.8$ & $108 \pm 43$ & 4.7 & 1.4 \\
Spleen & $668 \pm 186$ & $2.6 \pm 1.2$ & $93.9 \pm 28.8$ & 33.1 & 9.9 \\
Kidneys & $1502 \pm 466$ & $7.0 \pm 3.6$ & $107 \pm 33$ & 14.7 & 4.4 \\
Lung & $1044 \pm 192$ & $3.9 \pm 1.5$ & $86.3 \pm 27.5$ & 21.2 & 6.4 \\
RBC & $1569 \pm 344$ & $5.0 \pm 3.5$ & $72.5 \pm 17.1$ & 14.1 & 4.2 \\
Plasma & $1984 \pm 733$ & $2.7 \pm 1.3$ & $34.5 \pm 11.2$ & 11.2 & 3.3 \\
Cerebellum & $2978 \pm 23$ & $0.7 \pm 0.1$ & $\mathbf{5 7 . 4} \pm \mathbf{7 . 7}$ & $\mathbf{5 4 . 1}$ & 16.2 \\
Olfactory bulb $(n=32)$ & $48.4 \pm 5.2$ & $0.3 \pm 0.1$ & $150 \pm 63$ & 333 & 99 \\
5 Olfactory bulbs $(n=12)$ & $239 \pm 17$ & $0.6 \pm 0.1$ & $\mathbf{6 1 . 4} \pm \mathbf{1 0 . 9}$ & $\mathbf{6 7 . 5}$ & 20.2 \\
Hippocampus $(n=32)$ & $51.6 \pm 8.6$ & $0.2 \pm 0.1$ & $116 \pm 44$ & 311 & 93 \\
5 Hippocampus $(n=12)$ & $251 \pm 45$ & $0.6 \pm 0.1$ & $\mathbf{6 6 . 1} \pm \mathbf{9 . 2}$ & $\mathbf{6 4 . 0}$ & 19.2 \\
5 Frontal cortex $(n=18)$ & $351 \pm 57$ & $0.8 \pm 0.1$ & $\mathbf{5 7 . 3} \pm \mathbf{1 0 . 1}$ & $\mathbf{4 5 . 8}$ & 13.7 \\
Urine & $3000 \pm 281$ & $11.0 \pm 1.6$ & $95.6 \pm 19.2$ & 7.4 & 2.2 \\
\hline
\end{tabular}

Notes: data were obtained from 62 rats. Masses in italics mean that the tissue or the sample was not taken entirely. LOQ in this table is equivalent to MQL.

by both ICP-MS and AAS. For ICP-MS analysis in CRI mode, no matrix interferences on ${ }^{49} \mathrm{Ti}$, such as ${ }^{33} \mathrm{~S}^{16} \mathrm{O},{ }^{32} \mathrm{~S}^{16} \mathrm{O}^{1} \mathrm{H}$ or ${ }^{31} \mathrm{P}^{18} \mathrm{O}$, were observed. Direct AAS analysis of non-mineralized samples and ICP-MS analysis of mineralized samples (method C, corrected for recovery) yielded titanium contents that usually differed by no more than $5 \%$.

Application of method $\mathrm{C}$ to different types of biological organ tissues. Table 4 presents the titanium contents measured in different rat organs. Mean titanium concentrations are reported as " $\mu \mathrm{g} / \mathrm{L}$ of final digestion solution" and "ng/g of tissue." As the MQL is dependent on the sample mass, it is reported as " $\mathrm{ng} / \mathrm{g}$ of tissue".

As mentioned above, the LOQ for method $\mathrm{C}$ (as determined from blank analyses) was $0.9 \mu \mathrm{g} / \mathrm{L}$ (Table 3). In the rat tissue tests, the MQL ranged from 4.7 (in liver) to $330 \mathrm{ng} / \mathrm{g}$ (in a single olfactory bulb), depending on the sample mass and digestion method used. This important finding should be taken into consideration in future toxicological studies. Because the basal titanium content is highly variable from one organ to another, it is necessary to ensure that the measured titanium concentration is above the MQL for meaningful quantification. The number of control animals is also relatively important $(n=62$ in this study) in ensuring that statistically significant results are obtained.

In Table 4, even though the titanium contents were measured in different control animals, when the measured concentrations were close to the MQL, such as those of cerebellum, 5 olfactory bulbs, 5 hippocampus and 5 frontal cortices, the respective standard deviations $(13.4,17.7,13.9$ and $17.6 \%$; Table 4$)$ were acceptable. Taking into account the variability between animals, according to the Horwitz test these standard deviations confirm that the method detection and quantification limits are appropriate.

The standard deviations for organs with relatively high titanium concentrations, such as the brain, liver, spleen, kidney, lung or RBC are equal to $23.8,39.8$, $30.7,31.5,31.8$ and $23.5 \%$, respectively. Standard deviations at this level are frequently reported for the titanium contents of the major rat tissues [15, 18].

The MQL and method detection limit (MDL) are on the same order of magnitude as those found in the literature. Krystek et al. [15] proposed an MDL of $5 \mathrm{ng} \mathrm{Ti} / \mathrm{g}$ tissue for liver, spleen, kidneys and blood. Our MDL are close to that level for kidneys and RBC (4.4 and $4.2 \mathrm{ng} \mathrm{Ti} / \mathrm{g}$ tissue, respectively) but deviate from this value for liver and spleen (1.4 and $9.9 \mathrm{ng} \mathrm{Ti} / \mathrm{g}$ tissue, respectively). The MQL and MDL expressed in "ng Ti/g tissue" are tissue mass-dependent and this 
should be kept in mind when results of future toxicokinetic studies are presented.

The titanium contents measured in brain $(75 \pm$ $18 \mathrm{ng} / \mathrm{g}$ ), liver (108 $\pm 43 \mathrm{ng} / \mathrm{g})$, spleen $(94 \pm 29 \mathrm{ng} / \mathrm{g})$, kidney (107 $\pm 34 \mathrm{ng} / \mathrm{g})$, lung ( $86 \pm 27 \mathrm{ng} / \mathrm{g})$ and RBC $(73 \pm 17 \mathrm{ng} / \mathrm{g})$ are relatively close to those reported by Wang et al. $(n=80)$ [22] and Liu et al. $(n=70)$ [23] in CD-1 mice. However, our results differ by one order of magnitude with those obtained by Fabian [8] (e.g., $(1.6 \pm 0.1) \times 10^{3} \mathrm{ng} / \mathrm{g}$ in rat lung compared to $86 \pm$ $27 \mathrm{ng} / \mathrm{g}$ in our study) and Shinohara [30] (e.g. $5.0 \pm$ $2.2 \mathrm{ng} / \mathrm{g}$ in rat kidney compared to $107 \pm 34 \mathrm{ng} / \mathrm{g}$ in our study). These discrepancies may be due to the number of rats ( $n=3$ for Fabian and $n=25$ for Shinohara) and/or the species of rat (Wistar and F344/DuCrlCrlj rats, respectively) used in the different studies.

Finally, it is worth mentioning that Krystek et al. [15] compared different digestion methods (using HF) in different laboratories. The inter-laboratory study yielded consistent results for samples over $4 \mu \mathrm{g} / \mathrm{g}$ tissue. However, all control rat tissue samples have titanium contents lower than $0.15 \mu \mathrm{g} / \mathrm{g}$ tissue, their method quantification limit. In our work, the method we chose is sensitive enough to quantify titanium in all control rat organs/tissues except single olfactory bulbs and hippocampus.

The aim of this study was to compare and validate a method for quantifying titanium content in biological samples. Four mineralization methods were tested for recovery and quantification limit. The best results were obtained for a method that involved mineralization with nitric and hydrofluoric acid, leading to $96 \pm$ $8 \%$ recovery and an LOQ down to $0.9 \mu \mathrm{g} / \mathrm{L}$ for a $\mathrm{TiO}_{2}-\mathrm{NPs}$ suspension. A wide variety of rat organs were then analysed using this method. These showed that the MQL was matrix-dependent. For example, the method is not sensitive enough to quantify titanium levels in a single olfactory bulb and hippocampus in control rats. Bearing this limitation in mind, the method could be applicable to in vivo studies of $\mathrm{TiO}_{2}-\mathrm{NPs}$ biokinetics and toxicokinetics studies and could also be transposed to human urine for biological monitoring of workers exposed to $\mathrm{TiO}_{2}-\mathrm{NPs}$. The nanotoxicology community is now fully aware of the need for a thorough characterization of the nanoobjects used in their studies independently from any information provided by the supplier. This study has highlighted that the same attention should be paid to ICP-MS quantification: no matter how tedious it might be, determining recovery rates and MQL of methods is a sine qua none condition for providing valuable data.

\section{ACKNOWLEDGMENTS}

The authors thank the French Alternative Energies and Atomic Energy Commission (CEA) and the
National Institute for Research and Safety (INRS). The authors particularly acknowledge the efforts of Alice Williams, Lise Merlen, Stéphane Boucard, Samuel Müller, Frédéric Cosnier and Robert Devoy for their technical assistance. This work has also benefited from the facilities and expertise of the Platform for TEM of Imagif (Centre de Recherche de Gif, wwww.imagif.cnrs.fr).

\section{REFERENCES}

1. Hendren, C.O., Mesnard, X., Dröge, J., and Wiesner, M.R., Environ. Sci. Technol., 2011, vol. 45, no. 7 , p. 2562.

2. Occupational Exposure to Titanium Dioxide, Current Intelligence Bulletin 63, 2011 DHHS (NIOSH), publ. no. 2011-160.

3. Threshold Limit Values and Biological Exposure Indices for 1992-1993, Cincinnati, Ohio: American Conference of Governmental Industrial Hygienists, 1992.

4. Lee, K.P., Trochimowicz, H.J., and Reinhardt, C.F., Toxicol. Appl. Pharmacol., 1985, vol. 79, p. 179.

5. IARS: Carbon Black and Titanium Dioxide, IARC Monographs, 2010, vol. 93.

6. Iavicoli, I., Leso, V., and Bergamaschi, A., J. Nanomater., 2012, 964381.

7. Shi, H., Magaye, R., Castranova, V., and Zhao, J., Part. Fibre Toxicol., 2013, vol. 10, no. 15, p. 1.

8. Fabian, E., Landsiedel, R., Ma-Hock, L., Wiench, K., Wohlleben, W., and van Ravenzwaay, B., Arch. Toxicol., 2008, vol. 82, no. 3, p. 151.

9. Xie, G., Wang, C., Sun, J., and Zhong, G., Toxicol. Lett., 2011, vol. 205, p. 55.

10. Ze, Y., Sheng, L., Zhao, X., Hong, J., Ze, X., Yu, X., Pan, X., Lin, A., Zhao, Y., Zhang, C., Zhou, Q., Wang, L., and Hong, F., J. Hazard. Mater., 2014, vol. 264, p. 219.

11. Janer, G., Mas del Molino, E., Fernández-Rosas, E., Fernández, A., and Vázquez-Campo, S., Toxicol. Lett., 2014, vol. 228, no. 2, p. 103.

12. Bencsik, A. and Lestaevel, P., J. Biomed. Mater. Res., Part A, 2014, p. 1.

13. Potouridis, T., Völker, J., Alsenz, H., Oetken, M., and Püttmann, W., Anal. Bioanal. Chem., 2014, vol. 406, no. 11, p. 2495.

14. López-Heras, I., Madrid, Y., and Cámara, C., Talanta, 2014, vol. 124, p. 71.

15. Krystek, P., Tentschert, J., Nia, Y., Trouiller, B., Noël, L., Goetz, M.E., Papin, A., Luch, A., Guérin, T., and de Jong, W.H., Anal. Bioanal. Chem., 2014, vol. 406, p. 3853.

16. Korn, M.D.A., Ferreira, A.C., Costa, A.C.S., Nobrega, J.A., and Silva, C.R., Microchem. J., 2002, vol. 71, p. 41.

17. Lomer, M.C.E., Thompson, R.P.H., Commisso, J., Keen, C.L., and Powell, J.J., Analyst, 2000, vol. 125, p. 2339.

18. Sarmiento-Gonzalez, A., Encinar, J.R., MarchanteGayon, J.M., and Sanz-Medel, A., Anal. Bioanal. Chem., 2009, vol. 393, p. 335. 
19. Sun, H.W., Zhang, X.Z., Niu, Q., Chen, Y.S., and Crittenden, J.C., Water, Air, Soil Pollut., 2007, vol. 178, p. 245.

20. Wildhagen, D., Krivan, V., Gercken, B., and Pavel, J., J. Anal. At. Spectrom., 1996, vol. 11, p. 371.

21. Directive 2010/63/EU on the approximation of laws, European Union, September 22, 2010.

22. Wang, J., Zhou, G., Chen, C., Yu, H., Wang, T., Ma, Y., Jia, G., Gao, Y., Li, B., Sun, J., Li, Y., Jiao, F., Zhao, Y., and Chai, Z., Toxicol. Lett., 2007, vol. 168, p. 176.

23. Liu, H., Ma, L., Zhao, J., Liu, J., Yan, J., Ruan, J., and Hong, F., Biol. Trace Elem. Res., 2009, vol. 129, p. 170.

24. Khosravi, K., Hoque, M.E., Dimock, B., Hintelmann, H., and Metcalfe, C.D., Anal. Chim. Acta, 2012, vol. 713, p. 86.
25. Yip, Y. and Sham, W., TrAC Trends Anal. Chem., 2007, vol. 26, p. 727.

26. Devoy, J., Melczer, M., Antoine, G., Remy, A., and Heilier, J.F., Anal. Bioanal. Chem., 2013, vol. 405, p. 8327.

27. Peters, F.T., Drummer, O.H., and Musshoff, F., Forensic Sci. Int., 2007, vol. 165, p. 216.

28. Carnrick, G.R., Lumas, B.K., and Barnett, W.B., J. Anal. At. Spectrom., 1986, vol. 1, p. 443.

29. Cal-Prieto, M.J., Felipe-Sotelo, M., Carlosena, A., Andrade, J.M., Lopez-Mahia, P., Muniategui, S., and Prada, D., Talanta, 2002, vol. 56, p. 1.

30. Shinohara, N., Danno, N., Ichinose, T., Sasaki, T., Fukui, H., Honda, K., and Kamo, M., Nanotoxicology, 2014, vol. 8, p. 132. 